Gut, 1989, 30, 955-958

\title{
T-cell and plasma cell populations in coeliac small intestinal mucosa in relation to dermatitis herpetiformis
}

\author{
D JENKINS, ANNE GOODALL, AND B SCOTT \\ From the Departments of Medicine and Pathology, Lincoln County Hospital, Lincoln
}

SUMMARY Differential lymphocyte and plasma cell counts and measurements of mucosal architecture were studied in small intestinal biopsies from 17 controls and 17 patients with untreated uncomplicated coeliac disease of whom five also had dermatitis herpetiformis. Intraepithelial T-cell and plasma cell counts and measurements of mucosal architecture were not significantly different in the two coeliac groups but both groups differed from the controls. Lamina propria T-cell counts were significantly higher in the patients who also had dermatitis herpetiformis than in uncomplicated coeliac disease, with a significant increase in the Leu 2 (CD8) positive (cytotoxic/suppressor) $T$-cell subset. This suggests a specific abnormality of $T$-cell control of immune responsiveness in the pathogenesis of the skin manifestations of dermatitis herpetiformis which is not found in uncomplicated coeliac disease.

Patients with coeliac disease and the majority of patients with dermatitis herpetiformis $(\mathrm{DH})$ have a very similar intestinal lesion. ${ }^{\prime 2}$ Like coeliac disease, $\mathrm{DH}$ responds to a strict gluten free diet and relapses after gluten challenge. ${ }^{3}$ In each condition there is evidence of disturbance of both cell mediated and humoral immunity in the small intestinal mucosa. ${ }^{34}$ It is, however, uncertain whether gluten sensitivity in all patients is caused by a single mechanism or whether various mechanisms may operate in different individuals. Neither is it clear whether specific immunological changes might be found in the small intestinal mucosa of patients with $\mathrm{DH}$ which are different from those in coeliac disease.

The relationship of coeliac disease to specific HLA types suggests that there are genetic factors controlling the pattern of immune response in susceptible individuals. ${ }^{5}$ Evidence that there can be heterogeneity in these responses comes from the demonstration that among coeliac patients on a gluten free

Address for correspondence: Dr Brian Scott, County Hospital, Sewell Road, Lincoln LN2 5QY.

Accepted for publication 16 November 1988. diet, antigliadin antibody was increased only in those having the immunoglobulin heavy chain constant region allotype marker $\mathrm{G} 2 \mathrm{~m}(\mathrm{n}){ }^{6}$

To search for any differences in pattern of small intestinal mucosal T-cell and plasma cell populations among patients with coeliac disease and $\mathrm{DH}$, differential counts of $\mathrm{T}$-cells and of plasma cell isotypes were performed. Prospective statistical exploration of data from a previous study using cluster analysis had suggested that such differences might exist in coeliac patients with and without $\mathrm{DH}$. Significant differences in the size of lamina propria Tcell populations were shown, although intraepithelial T-cell and plasma cell counts and measurements of mucosal architecture were not significantly different.

\section{Methods}

CONTROL SUBJECTS

Seventeen patients $(10$ men) undergoing routine small bowel biopsy for the investigation of diarrhoea or anaemia who were found to have no evidence of small bowel disease. Median age 29 years (range 14-69). 
COELIAC DISEASE PATIENTS

Seventeen patients (seven men) undergoing routine small bowel biopsy for the investigation of suspected small bowel disease. Biopsies from all these patients showed either subtotal or severe partial villous atrophy. All subsequently showed marked clinical improvement on treatment with a gluten free diet and on further biopsy all have shown unequivocal histological improvement. Median age 49 years (range 8-69).

Five of these patients also had a rash suggestive of dermatitis herpetiformis. In one patient the condition was diagnosed before referral for small bowel biopsy, whilst in the remaining four a rash first developed at four, eight, eight, and 13 months respectively after commencing a gluten free diet. Both patients tested for dermal $\operatorname{IgA}$ were positive. All three of the five $\mathrm{DH}$ patients tested had the typical HLA type of coeliac disease, HLA-B8, DR3. There were no differences in family history, age of onset, severity of symptoms or histological response to a gluten free diet between the groups of coeliac patients with and without $\mathrm{DH}$.

SMALL INTESTINAL BIOPSIES

Small intestinal biopsy, tissue processing, staining for IgM, IgG, and IgA plasma cells by the PAP technique and for $\mathrm{T}$-cell antigens using an avidinbiotin method on frozen tissue were carried out as previously described. ${ }^{4}$ Of the T-cell antigens used, the CD3 antigen is the closest approximation to a pan-T antigen, Leu 1 (CD5) is an antigen found on all circulating T-cells and thymocytes, and Leu 9 (CD7) is found on human T-cells and null cells. Leu 2 has been regarded as a marker for the cytotoxic/suppressor (CD8+) subset of T-cells, and Leu 3 as a marker for the helper/inducer (CD4+) subset. All antibodies except anti-CD3 were obtained from BectonDickinson, Sunnyvale, California, USA. Anti-CD3, as UCHT1, was donated by Dr P Beverley, ICRF Tumour Immunology Unit, University College Hospital, London.

MEASUREMENTS AND STATISTICAL ANALYSIS Measurements and cell counts on the stained sections were carried out using a MOPPET image analyser as described previously. ${ }^{7}$ The following measurements were made: mucosal length - length of the muscularis mucosae; area of lamina propria per millimetre mucosal length (MLA) - index of oedema; length of the villous/surface epithelium per mm mucosal length (MLS) - index of villous atrophy; length of crypt epithelium per mm mucosal length. The following cell counts were made: UCHT1, Leu 1, Leu 2, Leu 3, and Leu 9 positive cells in the villous/surface epithelium, crypt epithelium, and lamina propria;
$\operatorname{IgA}, \operatorname{IgG}$, and $\operatorname{IgM}$ containing plasma cells in the lamina propria. Only Leu 3 staining cells with a definite rim of peroxidase staining were counted, to exclude low density staining of monocytes and macrophages.

Cell counts were expressed both as cells $/ \mathrm{mm}$ mucosal length (VM,CM) and as cells $/ \mathrm{mm}$ epithelium (VE,CE) for intraepithelial lymphocytes, and as cells $/ \mathrm{mm}$ mucosal length for plasma cells and lamina propria T-cells.

Count variables were transformed by taking logarithms of the counts. Group means for each variable were compared using a two-tailed $t$ test. Bonferroni significance values are given throughout, to compensate for the large number of $t$ tests performed.

\section{Results}

Counts of the number of T-cells in each compartment positive for each of the five T-cell markers, plasma cells, MLS, and MLA were compared in the controls and in the 17 untreated coeliacs, five with and 12 without DH. Table 1 shows the derived means and ranges of counts for each $T$-cell antigen in surface epithelium in each group, Table 2 the derived means and ranges of T-cell counts in crypt epithelium, and Table 3 the derived means and ranges of counts of both $\mathrm{T}$-cells and plasma cells in the lamina propria. In uncomplicated coeliacs the mean of individual MLA values was 0.272 (range $0.204-0.350$ ) and in $\mathrm{DH}$ patients the mean was $0 \cdot 256$ (range $0 \cdot 186-0 \cdot 327$ ); the values are not significantly different. In the control

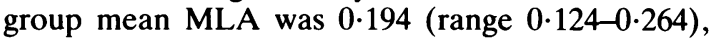

Table 1 Derived means of small-intestinal mucosa T-cell counts in surface epithelium

\begin{tabular}{|c|c|c|c|c|c|c|}
\hline & \multicolumn{2}{|c|}{ Controls } & \multicolumn{2}{|l|}{$U C D$} & \multicolumn{2}{|l|}{$D H$} \\
\hline & Mean & $95 \% C L$ & Mean & $95 \% C L$ & Mean & $95 \% C L$ \\
\hline \multicolumn{7}{|c|}{ (a) cells/mm surface epithelium } \\
\hline T3 & 32 & $25-41$ & 115 & $93-141 \dagger$ & 144 & $82-254 \dagger$ \\
\hline Leu 1 & 16 & $12-23$ & 52 & $23-119+$ & 70 & $31-161 \dagger$ \\
\hline Leu 2 & 24 & $18-33$ & 65 & $43-97 \dagger$ & 74 & $39-141^{*}$ \\
\hline Leu 3 & 2 & $2-3$ & 8 & $5-13+$ & 10 & $3-29 \dagger$ \\
\hline Leu 9 & 33 & $27-42$ & 98 & $72-135 \dagger$ & 101 & $46-221+$ \\
\hline \multicolumn{7}{|c|}{ (b) cells/mm mucosal length } \\
\hline T3 & 128 & $95-172$ & 148 & $100-218$ & 177 & $120-262$ \\
\hline Leu 1 & 62 & $42-90$ & 58 & $35-97$ & 83 & $56-124$ \\
\hline Leu 2 & 97 & $68-138$ & 72 & $45-117$ & 99 & $66-149$ \\
\hline Leu 3 & 7 & $5-12$ & 8 & $5-15$ & 12 & $5-31$ \\
\hline Leu 9 & 145 & $108-195$ & 96 & $55-169$ & 160 & $111-231$ \\
\hline
\end{tabular}

Note: UCD - Uncomplicated coeliac disease; $p$ values for comparisons of coeliac groups with controls: ${ }^{*}<0.01$ Bonferroni significance values; $\nmid<0 \cdot 001$ Bonferroni significance values. None of the differences between the two coeliac groups are significant. 
Table 2 Derived means of small-intestinal mucosa T-cell counts in crypt epithelium

\begin{tabular}{|c|c|c|c|c|c|c|}
\hline & \multicolumn{2}{|c|}{ Controls } & \multicolumn{2}{|l|}{$U C D$} & \multicolumn{2}{|l|}{$D H$} \\
\hline & Mean & $95 \% C L$ & Mean & $95 \% C L$ & Mean & $95 \% C L$ \\
\hline \multicolumn{7}{|c|}{ (a) cells/mm crypt epithelium } \\
\hline T3 & 7 & $5-11$ & 17 & $14-22 \dagger$ & 22 & $8-56 \dagger$ \\
\hline Leu 1 & 6 & $4-7$ & 9 & $5-14$ & 7 & $2-32$ \\
\hline Leu 2 & 8 & $6-11$ & 12 & $8-17$ & 8 & $2-27$ \\
\hline Leu 3 & 2 & $1-2$ & 2 & $1-3$ & 2 & $0-9$ \\
\hline Leu 9 & 9 & $6-11$ & 18 & $12-25 t$ & 13 & $6-29 \dagger$ \\
\hline \multicolumn{7}{|c|}{ (b) cells/mm mucosal length } \\
\hline T3 & 43 & $30-60$ & 150 & $107-209 \ddagger$ & 162 & $134-196 \ddagger$ \\
\hline Leu 1 & 36 & $26-50$ & 72 & $43-121$ & 55 & $16-193$ \\
\hline Leu 2 & 46 & $34-63$ & 96 & $71-129+$ & 52 & $21-130$ \\
\hline Leu 3 & 8 & $6-12$ & 10 & $5-12$ & 8 & $1-40$ \\
\hline Leu 9 & 48 & $38-61$ & 141 & $116-172 \ddagger$ & 92 & $31-272^{*}$ \\
\hline
\end{tabular}

Note: UCD - Uncomplicated coeliac disease; $p$ values for comparisons of coeliac groups with controls: ${ }^{*}<0.05$ Bonferroni significance values; $\nmid<0.01$ Bonferroni significance values; $\ddagger<0.001$ Bonferroni significance values. None of the differences between the two coeliac groups are significant.

Table 3 Derived means of small-intestinal mucosa T-cells and plasma cells in lamina propria (counts/mm mucosal length

\begin{tabular}{|c|c|c|c|c|c|c|}
\hline & \multicolumn{2}{|c|}{ Controls } & \multicolumn{2}{|l|}{$U C D$} & \multicolumn{2}{|l|}{$D H$} \\
\hline & Mean & $95 \% C L$ & Mean & $95 \% C L$ & Mean & $95 \% C L$ \\
\hline $\mathrm{T} 3$ & 272 & $213-347^{*}$ & 370 & $260-527$ & 615 & 417-907 \\
\hline Leu 1 & 319 & $261-390 *$ & 281 & 199-397* & 546 & $362-823$ \\
\hline Leu 2 & 118 & $89-157 \dagger$ & 127 & $99-162 *$ & 278 & $190-407$ \\
\hline Leu 3 & 259 & $206-327$ & 312 & $238-409$ & 433 & $241-768$ \\
\hline Leu 9 & 162 & $126-208 \ddagger$ & 196 & $147-263+$ & 516 & $333-802$ \\
\hline $\operatorname{Ig} A$ & 318 & $276-367$ & 649 & $507-830 \|$ & 721 & $519-1002$ \\
\hline IgM & 98 & $78-122$ & 292 & $221-385 \|$ & 242 & $156-376 \|$ \\
\hline IgG & 49 & $33-73$ & 97 & $57-162$ & 148 & $48-455 \S$ \\
\hline
\end{tabular}

Note: UCD - Uncomplicated coeliac disease; $p$ values for comparisons. With DH group: $*<0 \cdot 05$ Bonferroni significance values; $\uparrow<0 \cdot 01$ Bonferroni significance values; $\neq<0.001$ Bonferroni significance values. With controls: $\S<0.05$ Bonferroni significance values; $\|<0.001$ Bonferroni significance values.

significantly lower than both coeliac groups $(\mathrm{p}<0.001$ for uncomplicated coeliac disease, (0.005 for $\mathrm{DH})$. Mean MLS value in the uncomplicated coeliacs was 1.68 (range $1.06-2.57$ ), in the DH patients 1.95 (range 1.26-3.42), and in the controls 5.50 (range 6.60-9.34). Again there was no significant difference between the two coeliac groups, but both differed significantly from the control group $(\mathrm{p}<0.001$ in both cases).

From the Tables it can be seen that there were also no significant differences in any $\mathrm{T}$-cell count in villous or crypt epithelium or in any plasma cell count between the two coeliac groups, although both differed significantly from the controls. There were, however, significant differences between the two coeliac groups in T-cell counts in the lamina propria.

\section{Discussion}

This study shows that although patients with uncomplicated coeliac disease and patients with $C D$ associated with the characteristic manifestations of DH may have histology which is indistinguishable, with the same extent of villous atrophy and apparently identical intraepithelial T-cell and lamina propria plasma cell populations, they show significant differences between the $T$ cell populations in the lamina propria.

In a previous study we have suggested that the significant increase in the density of $T$ cells per unit length of surface epithelium and associated changes in Leu 1 (CD5), Leu 2 (CD8), and Leu 5 (CD2) expression indicate a distinctive population of intraepithelial $T$ cells in coeliac disease. ${ }^{4}$ The present study shows that there are very similar, perhaps identical, changes in these cells in DH. The uniform finding of these characteristic intraepithelial $\mathrm{T}$ cells and the similarity of their phenotype to that of $T$ cell lymphoma arising in coeliac disease supports the suggestion that the pathogenesis of coeliac disease involves an abnormal polyclonal proliferation of $\mathrm{T}$ cells. ${ }^{8}$

As well as finding no difference in intraepithelial Tcells, the coeliac patients with and without DH showed no significant differences in measurements of villous atrophy or oedema (mucosal volume). Within the lamina propria, however, significantly higher counts of total T cells, identified by UCHT1 (CD3), Leu 1 (CD5), and Leu 9 (CD7) positivity, were found in patients with $\mathrm{DH}$ than in those with uncomplicated coeliac disease. The significant increase in Leu 2 (CD8) + cells suggests that much of this must be caused by an increase in the cytotoxic/suppressor subset. The identification of the two subgroups explains the wide range of lamina propria $T$ cell counts in the overall coeliac population which we have previously reported, with some clearly outside the normal range, but a mean close to that of the controls. ${ }^{4}$ It is also consistent with the report by Selby and colleagues of a slight but significant increase in the proportion of lamina propria $\mathrm{CD} 8+$ cells in a group of untreated coeliac patients amongst whom the presence of DH lesions was not defined. ${ }^{9}$

Although a significant increase in $\operatorname{IgA}$, IgM, and IgG plasma cells was confirmed for both $\mathrm{DH}$ and uncomplicated coeliacs over controls, in the small numbers studied there were no significant differences between the $\mathrm{DH}$ and coeliac groups. The finding of raised plasma cell counts is in line with previous results for both DH and coeliac disease. ${ }^{3710}$ 
The pathogenesis of DH still needs clarification. In both $\mathrm{DH}$ and coeliac disease much attention is focused on the role of the $T$ cells in the surface epithelium..$^{3+4-11}$ The results of this study support the suggestion that this is central to the pathogenesis of gluten sensitivity in both conditions. In the skin of patients with $\mathrm{DH} \operatorname{IgA}$ deposition is a major feature. ${ }^{12}$ This $\operatorname{IgA}$ is dimeric and originates in secretory cells. ${ }^{13}$ The $\operatorname{IgA}$ reaction in the small intestinal mucosa has been closely related to the development of the rash in $\mathrm{DH} .{ }^{3}$ There is evidence that $\operatorname{IgA}$ is regulated by a complex interaction of isotype specific $T$ cells present in gut lymphoid tissue, ${ }^{14}$ and in mice it has been shown that oral antigen can induce simultaneously from Peyer's patches $\operatorname{IgA}$ helper $\mathrm{T}$ cells and also cells which can suppress IgG. ${ }^{15}$ It has previously been suggested that the lamina propria $T$ cells have a very different immunological role from surface epithelial $\mathrm{T}$ cells. ${ }^{16}$ It is possible that the increased total and $\mathrm{CD} 8+\mathrm{T}$ cell population in the lamina propria of the small intetine in DH may indicate an additional specific abnormality of $T$ cell control of immunoglobulin production involved in the pathogenesis of the skin manifestations of $\mathrm{DH}$.

We are very grateful to the Coeliac Trust for generous financial support. We also thank $\mathrm{Mr} \mathrm{B}$ Thornton for technical help.

\section{References}

1 Marks J, Shuster S, Watson AJ. Small bowel changes in dermatitis herpetiformis. Lancet 1966; ii: 1280-2.

2 Brow JR, Parker F, Weinstein WM, Rubin CE. The small intestinal mucosa in dermatitis herpetiformis. 1. Severity and distribution of the small intestinal lesion and associated malabsorption. Gastroenterology 1972; 60: $355-61$.

3 Kosnai I. Karpati S, Savilahti E, Verkasalo M, Bucsky $P$, Torok E. Gluten challenge in children with dermatitis herpetiformis: a clinical, morphological and immunohistological study. Gut 1986; 27: 1464-70.

4 Jenkins D. Goodall A. Scott BB. T-lymphocyte popula- tions in normal and coeliac small intestinal mucosa defined by monoclonal antibodies. Gut 1986; 27: 1330-7.

5 Kagnoff MF. Coeliac disease: genetic, immunological and environmental factors in disease pathogenesis. Scand J Gastroenterol 1985; 20 [suppl 114]: 45-54.

6 Weiss JB, Austin RK. Schanfield MS. Kagnoff MF. Gluten-sensitive enteropathy. Immunoglobulin $G$ heavy chain $(\mathrm{Gm})$ allotypes and the immune response to wheat gliadin. J Clin Invest 1983; 72: 96-101.

7 Scott BB, Goodall A, Stephenson P, Jenkins D. Small intestinal plasma cells in coeliac disease. Gut 1984; 25: $41-6$.

8 Isaacson PG, O`Connor NT, Spencer S, et al. Malignant histiocytosis of the intestine; a T cell lymphoma. Lancet 1985; ii: 688-91.

9 Selby WS, Janossy G, Bofil MA, Jewell DP. Lymphocyte subpopulations in the human small intestine. The findings in normal mucosa and in the mucosa of patients with adult cocliac discasc. Clin Exp Immunol 1983; 52: 219-28.

10 Lancaster-Smith M, Joyce S, Kumar P. Immunoglobulins in the jejunal mucosa in adult coeliac disease and dermatitis herpetiformis after the reintroduction of dietary gluten. Gut 1977; 18: 887-91.

11 Fry L. Seah PP. Harper PG, Hoffbrand AV, McMinn $\mathrm{RMH}$. The small intestine in dermatitis herpetiformis. J Clin Pathol 1974; 27: 817-24.

12 Marsden RA, McKee PH, Bhogal B, Black MM, Kennedy LA. A study of benign chronic bullous dermatosis of childhood and comparison with dermatitis herpetiformis and bullous pemphigoid occurring in childhood. Clin Exp Dermatol 1980; 5: 159-72.

13 Unsworth DJ, Payne AW, Leonard JN, Fry L, Holborrow EJ. IgA in dermatitis herpetiformis skin is dimeric. Lancet 1982; i: 478-80.

14 Elson CO. Induction and control of the gastrointestinal immune system. Scand J Gastroenterol 1985; 20 [suppl 114]: $1-15$.

15 Richman LK. Graeff AS, Yarchoan R, Strober W. Simultaneous induction of antigen-specific IgA helper $T$ cells and IgG suppressor T cells in the murine Peyer's patch after protein feeding. J Immunol 1981; 126: 207983.

16 Selby WS, Janossy G, Goldstein G, Jewell DP. T lymphocyte subsets in human intestinal mucosa - the distribution and relationship to MHC-derived antigens. Clin Exp Immunol 1981; 44: 453-8. 